\section{Elastofibroma dorsi: a histochemical and immunohistochemical study}

\author{
A. Di Vito, ${ }^{1}$ E. Scali, ${ }^{2}$ G. Ferraro, ${ }^{3}$ \\ C. Mignogna, ${ }^{4}$ I. Presta, ${ }^{4}$ C. Camastra, ${ }^{4}$ \\ C. Palmieri, ${ }^{1}$ G. Donato, ${ }^{4}$ T. Barni \\ 'Department of Clinical and Experimental \\ Medicine, Magna Græcia University of \\ Catanzaro \\ 2Department of Dermatology, Health \\ Science, Magna Græcia University of \\ Catanzaro Medical School \\ ${ }^{3}$ Clinical Institute Villa Aprica, Como \\ ${ }^{4}$ Department of Health Science, \\ Pathology Unit, Magna Græcia University \\ of Catanzaro Medical School, Italy
}

\section{Abstract}

Elastofibroma dorsi (ED) is considered a member of a heterogeneous group of benign fibrous (fibroblastic or myofibroblastic) softtissue tumors, frequently localized in the periscapular region in middle aged or older individuals. However, the pathogenesis of ED is still unclear and many authors believe that ED results from a reactive hyperproliferation of fibroblastic tissue, while others suggest that it may be a consequence of a mechanical friction. In our study, we examined 11 cases of ED using histochemical and immunohistochemical methods, in order to extend the knowledge about extracellular matrix composition and histopathogenesis of ED. From the results it appeared that stroma and interspersed spindle cells of ED were positive for both periostin and tenascin-C. Mast cells tryptase-positive were also abundant throughout the lesion. The perivascular distribution of periostin and tenascin-C, associated with the CD34 positivity, suggest that endothelial-mesenchymal transition events can account for neovascularization and production of fibroelastic tissue characteristic of elastofibroma. Our data obtained in endothelial cells cultures demonstrated that elastin production is higher when the status of confluence of the cells is low. So, we can assume that such a phenomenon is a characteristic of mesenchymal/endothelial cells CD34 positive, in which elastin production results to be inversely proportional to the vascular differentiation of cellular elements. In the light of these considerations, we think that a cancerous nature of ED is unlikely. Overall, our study report, for the first time, a detailed description of extracellular matrix composition in ED, suggesting that a mechanical strain-dependent reactivation of periostin and tenascin-C expression, as well as of elastin deposition, could be responsible for development of ED.

\section{Introduction}

Elastofibroma dorsi (ED) was first described by Järvi and Saxen in 1961 as a no encapsulated and slow growing lesion, characterized by abnormal elastic fibers in a stroma of collagen and fatty connective tissue. ${ }^{1}$ Elastofibroma is currently considered a member of a heterogeneous group of benign fibrous (fibroblastic or myofibroblastic) soft-tissue tumors, frequently localized in the periscapular region of middle aged or older individuals. The WHO defines elastofibroma as a benign, ill-defined proliferation of elastofibrous tissue characterized by an excessive number of abnormal elastic fibers. ${ }^{2}$ In particular, ED sites at the rhomboid major and latissimus dorsi muscles subjacent to the inferior angle of the scapula, ${ }^{3}$ and is often attached to the periosteum of the thoracic wall. ${ }^{4}$ In rare cases elastofibroma sites are the olecranon, orbits, greater trochanter, deltoid muscle, foot, inguinal region, tricuspid valve, stomach, greater omentum, axilla, and the intraspinal space..$^{5}$ Although it is usually unilateral, it may be bilateral in $10 \%$ of cases. The reported incidence is $0.23 / 100$ and is more common in females. ${ }^{5-7}$ Children are rarely affected. Patients often report symptoms of pain and uneasiness that in many cases become functionally debilitating. During clinical examination, a palpable and movable tumor, which usually does not show distinct margins to the surrounding soft-tissue, is the typical finding. ${ }^{8}$ The differential diagnosis includes subcutaneous tumors or lesions such as lipomas, fibrolipomas, cystic formations or more aggressive tumors. ${ }^{9}$

The pathogenesis of ED is still unclear, however, for a long time, it was considered to be a reactive lesion rather than a neoplastic one. Some authors suggest that elastofibroma is a proliferative response of the connective tissue to the mechanical stress due to repetitive trauma and manual labor. ${ }^{10}$ Geibel et al. (1996) suggest that ED results from a physiologic aging process, rather than abnormal elastogenesis or degeneration, based on the detection of pre-elastofibroma changes in their sample. ${ }^{11}$ In particular, they have observed a weakly elastinophilic material that does not show definite elastic tissue formation. In addition, from a review of the literature, it appears that many other factors could account for ED pathogenesis, including vascular insufficiency, ${ }^{12}$ degenerative changes in collagen, ${ }^{13}$ an enzymatic defect, ${ }^{14}$ and altered elastin fibrillogenesis by periosteal-derived cells. ${ }^{15}$ In the latest decade, the application of advanced genetic analysis
Correspondence: Prof. Giuseppe Donato, Department of Health Science, Pathology Unit, Magna Græcia University of Catanzaro Medical School, via T. Campanella, 88100 Catanzaro, Italy. Tel. +39.0961.712454 - Fax: +39.0961.712454.

E-mail: gdonato@unicz.it

G.D. and T.B. contribute equally to the paper.

Keywords: Elastofibroma dorsi, extracellular matrix, periostin, tenascin- $\mathrm{C}$, elastin, collagen.

Conflict of interest: the authors declare no conflict of interest.

Contributions: ADV, GD, TB, study design and paper writing; GF, CC, histology and immunohistochemistry; ES, cases critical selection; CM, histological evaluation; IP, cell culture and western blotting; CP, participation in manuscript revision and immunofluorescence. All authors revised and approved the final draft of the manuscript.

Received for publication: 6 November 2014.

Accepted for publication: 28 January 2015.

This work is licensed under a Creative Commons Attribution NonCommercial 3.0 License (CC BYNC 3.0).

(C) Copyright A. Di Vito et al., 2015

Licensee PAGEPress, Italy

European Journal of Histochemistry 2015; 59:2459 doi:10.4081/ejh.2015.2459

techniques provide us with evidences of genomic alterations in ED. Abnormalities of the short arm of chromosome 1 are seen in three cases of ED. ${ }^{16}$ Comparative genomic hybridization analyses have shown recurrent gains at Xq12-q22, ${ }^{17}$ and losses on 1p, 13q, 19p, and $22 \mathrm{q}$; in addition, deletion of CASR (3q21), GSTP1 (11q13), BRCA2 (13q12) and gains on APC (5q21) and PAH (12q23) are observed by MLPA in two cases of elastofibroma. ${ }^{18}$ Even though these results are suggestive of a possible neoplastic origin of the lesion, the precise role of chromosomal abnormalities in ED is not yet clarified.

The majority of authors have point their attention to histochemical, immunohistochemical, and ultrastructural properties of ED, in order to clarify two important issues: the nature of the cells, and the origin of abnormal elastic fibers and collagen fibers. It's reported the presence of CD34-positive fibroblasts, while only a few authors agree with the presence of myofibroblasts. ${ }^{10,19,20}$ As far as extracellular matrix is concerned, fibroblasts are able to produce and remodel the ECM in response to pro-fibrotic cytokines such as TGF- $\beta$ and others. However, molecular mechanisms involved in collagen and elastic fibers deposition in ED are less understood, and ECM is not 
completely characterized. On the basis of these considerations, we examined 11 cases of ED using histochemical and immunohistochemical methods, in order to extend the knowledge about ECM and histopathogenesis of ED. In addition, since in vascular smooth muscle and in fibroblasts the cell cycle control appears intimately associated with elastogenesis, ${ }^{21,22}$ we assessed the possibility that the elastin expression rate could be influenced in endothelial cells by mitotic drive.

\section{Materials and Methods}

\section{Specimens}

A retrospective evaluation of 11 histopathological specimens of ED, diagnosed at the Department of Pathology of the University of Catanzaro, from October 2011 to June 2014. In addition, normal ligamentum flavum of five patients operated for dorsal disc herniation were used as control. This study was approved by the ethical standards of the responsible institutional committee, and all subjects provided their informed consent. The cohort of patients with ED consisted of 4 females and 7 males, with a mean age of 60 years (range 4070 years). Tumor size ranged from 3 to $10 \mathrm{~cm}$. The lesions were all located at the inferior pole of the scapula, on the right in 5 cases, on the left in 6 cases. The clinical data for all the patients with ED are summarized in Table 1.

\section{Histology and immunohistochemistry}

After surgical excision specimens were fixed in $10 \%$ formalin and embedded in paraffin for the following histological examinations. Sections in $4 \mu \mathrm{m}$ thickness were stained with haematoxylin and eosin, alcian blue $\mathrm{pH} 2.5$ (for the visualization of sulfated and carboxylated acid mucopolysaccharides), with and without testicular bovine hyaluronidase treatment (Bio Optica, Milan, Italy), using standard techniques. Additionally, immunohistochemical staining was performed with an automated immunostainer (Bond TM Max). Antibodies against CD34 (Clone QBEnd10, 1:250 dilution; Dako, Milan, Italy), elastin (clone BA-4, 1:200; Leica Microsystems, Milan, Italy), tenascin-C (Clone clone 49, 1:100; Leica Microsystems), periostin (1:200, Abcam-ab1441; Milan, Italy), mast cell tryptase (clone 10D11, 1:150, Leica, Mannheim, Germany) were employed in the present study. All procedures were carried out at room temperature. Normal (non-hypertrophic) ligamentum flavum of five patients (age range 42-57) operated for dorsal disc herniation (T5-T12) were used as an elastic connective tissue for positive control of elastin and periostin. Intensity of stain was scored for the extent of positivity as follows: + , low positivity; ++ , intermediate positivity; +++ , high positivity. Immunohistochemical results were scored independently by two investigators.

\section{Double immunofluorescence staining}

For confocal microscopy, sections were first hydrated in decreasing ethanol gradient solutions and PBS 1X before permeabilisation and blocking with $100 \mu \mathrm{L}$ of $0.5 \%$ Saponin and $10 \%$ BSA in PBS $1 X$ for 30 min. In order to identify the distribution pattern of periostin, tenascin and CD34 in peripheral as well as central area of the specimens, two distinct double staining to detect periostin/tenascin and CD34 were performed. Briefly, all sections were incubated with antibody against CD34 for $30 \mathrm{~min}$, followed by secondary antibody Alexa Fluor 633conjugated anti-mouse IgG (Santa Cruz Biotechnologies, Santa Cruz, CA, USA), for 60 min. Afterwards, sections were incubated with antibodies against periostin or tenascin for 30 min, followed by secondary antibodies Alexa Fluor 488-conjugated anti-rabbit IgG or FITCconjugated anti-mouse IgG (1:400; Santa Cruz Biotechnology), respectively, for $60 \mathrm{~min}$. All procedures were carried out at room temperature. The cells were counterstained with DAPI
( $2 \mu \mathrm{g} / \mathrm{mL}$; Santa Cruz Biotechnology), mounted using an antifade mounting medium (Life Technologies, Monza, Italy) and observed at a Laser Confocal Scanning Microscopy (SP2 LSCM, Leica Microsystems). Single staining for CD34, periostin and tenascin-C, as well as negative controls were also carried out. The double immunofluorescence staining procedure was repeated three times.

\section{Cell culture}

The human umbilical vein endothelial cells (HUVEC) were plated in $60 \mathrm{~mm}$ plastic culture dishes and cultured in ECM medium (ScienCell, Innoprot, Derio-Biskaia, Spain) supplemented with 5\% FBS, 1X Endothelial Cells Growth Supplements, penicillin and streptomycin, at $37^{\circ} \mathrm{C}$ in a humidified atmosphere with $5 \%$ pp $\mathrm{CO}_{2}$. Fresh medium was replaced every $48 \mathrm{~h}$. Subcultures were obtained by trypsinization and were used for experiments at passages 3 to 5 . Elastin expression levels have been assessed at different confluence densities of HUVEC cell culture. HUVECs were seeded at a concentration of $8 \times 10^{5}$ cells/dish, allowed to attach overnight and cultured to an appropriate degree of confluence. Cells were harvested when they reached approximately $20 \%, 40 \% 60 \%$ and $100 \%$ of confluence.

\section{Western blot analysis}

After treatments, cells were washed twice with ice-cold PBS and lysed in ice-cold protein lysis buffer containing $50 \mathrm{mmol} / \mathrm{L}$ HEPES, $\mathrm{pH}$ 7.5, $150 \mathrm{mmol} / \mathrm{L} \mathrm{NaCl}, 10 \mathrm{mmol} / \mathrm{L}$ EDTA, $1 \%$ Triton X-100, $10 \mathrm{mmol} / \mathrm{L} \mathrm{Na}_{4} \mathrm{P}_{2} \mathrm{O}_{7}, 100 \mathrm{mmol} / \mathrm{L}$ $\mathrm{NaF}$ and $2 \mathrm{mmol} / \mathrm{L}$, supplemented with activated $\mathrm{Na}_{3} \mathrm{VO}_{4}, 1 \mathrm{X}$ protease inhibitor cocktail (Roche Diagnostics SpA, Monza, Italy) and 100 $\mathrm{mmol} / \mathrm{L}$ PMSF. Lysates were incubated at $4^{\circ} \mathrm{C}$ for $30 \mathrm{~min}$ and mixed intermittently using a vortex and then centrifuged at $12,000 \times \mathrm{g}$ for 15 min at $4{ }^{\circ} \mathrm{C}$. Supernatant was collected and protein concentration in each sample was deter-

Table 1. Clinical data of patients with elastofibroma dorsi.

\begin{tabular}{|c|c|c|c|c|c|c|c|c|c|c|c|}
\hline Clinical data & Case 1 & Case 2 & Case 3 & Case 4 & Case 5 & Case 6 & Case 7 & Case 8 & Case 9 & Case 10 & Case 11 \\
\hline Age/sex & $52 / F$ & $69 / \mathrm{F}$ & $47 / \mathrm{M}$ & $68 / \mathrm{M}$ & $50 / \mathrm{M}$ & $45 / \mathrm{M}$ & $46 / F$ & $48 / \mathrm{M}$ & $41 / \mathrm{M}$ & $70 / F$ & $54 / \mathrm{M}$ \\
\hline Occupation & Teacher & Housewife & Worker & Pensioner & Bank clerk & Engineer & Lawyer & Physiotherapist & Warehouseman & Housewife & Mechanic \\
\hline Tumor location & $\begin{array}{c}\text { Left } \\
\text { inferior } \\
\text { pole of the } \\
\text { scapula }\end{array}$ & $\begin{array}{l}\text { Left } \\
\text { inferior } \\
\text { pole of the } \\
\text { scapula }\end{array}$ & $\begin{array}{l}\text { Right } \\
\text { inferior } \\
\text { pole of the } \\
\text { scapula }\end{array}$ & $\begin{array}{l}\text { Right } \\
\text { inferior } \\
\text { pole of the } \\
\text { scapula }\end{array}$ & $\begin{array}{l}\text { Right } \\
\text { inferior } \\
\text { pole of the } \\
\text { scapula }\end{array}$ & $\begin{array}{c}\text { Left } \\
\text { inferior } \\
\text { pole of the } \\
\text { scapula }\end{array}$ & $\begin{array}{l}\text { Left } \\
\text { inferior } \\
\text { pole of the } \\
\text { scapula }\end{array}$ & $\begin{array}{l}\text { Left } \\
\text { inferior } \\
\text { pole of the } \\
\text { scapula }\end{array}$ & $\begin{array}{l}\text { Left } \\
\text { inferior } \\
\text { pole of the } \\
\text { scapula }\end{array}$ & $\begin{array}{l}\text { Right } \\
\text { inferior } \\
\text { pole of the } \\
\text { scapula }\end{array}$ & $\begin{array}{c}\text { Right } \\
\text { inferior } \\
\text { pole of the } \\
\text { scapula }\end{array}$ \\
\hline Tumor size & $5 \mathrm{~cm}$ & $10 \mathrm{~cm}$ & $7 \mathrm{~cm}$ & $10 \mathrm{~cm}$ & $7 \mathrm{~cm}$ & $4 \mathrm{~cm}$ & $6 \mathrm{~cm}$ & $3 \mathrm{~cm}$ & $7 \mathrm{~cm}$ & $4 \mathrm{~cm}$ & $6 \mathrm{~cm}$ \\
\hline Symptoms & $\begin{array}{c}\text { Pain } \\
\text { during } \\
\text { movement }\end{array}$ & $\begin{array}{l}\text { Pain and } \\
\text { click of } \\
\text { during } \\
\text { movement }\end{array}$ & $\begin{array}{l}\text { Pain and } \\
\text { limitation } \\
\text { of motion } \\
\text { range }\end{array}$ & $\begin{array}{c}\text { Pain } \\
\text { during } \\
\text { movement }\end{array}$ & $\begin{array}{l}\text { Limitation of } \\
\text { motion } \\
\text { range }\end{array}$ & Discomfort & $\begin{array}{l}\text { Clicking } \\
\text { sensation } \\
\text { during } \\
\text { movement }\end{array}$ & $\begin{array}{c}\text { Pain } \\
\text { during } \\
\text { movement }\end{array}$ & $\begin{array}{l}\text { Pain } \\
\text { and limitation } \\
\text { of motion range }\end{array}$ & $\begin{array}{c}\text { Pain } \\
\text { during } \\
\text { movement }\end{array}$ & $\begin{array}{c}\text { Pain } \\
\text { and limitation } \\
\text { of motion } \\
\text { range }\end{array}$ \\
\hline
\end{tabular}

F, female; M, male. 
mined using Bio-Rad protein assay kit (BioRad Laboratories Srl, Segrate, MI, Italy). Equal amounts of protein $(30 \mu \mathrm{g})$ of each sample were then subjected to electrophoresis through 7-10\% SDS polyacrylamide mini-gels then transferred by electroblotting to a nitrocellulose membrane (Amersham Pharmacia Biotech, Amersham, UK). Nonspecific antibody binding sites were blocked by incubating trans-blotted membranes with TTBS/milk (TBS, 0,1\% Tween 20, and 5\% non-fat dry milk) for $1 \mathrm{~h}$ at room temperature followed by overnight incubation at $4^{\circ} \mathrm{C}$ in TTBS/milk with a proper dilution of specific mouse primary antibodies raised against elastin and $\beta$-actin (Sigma-Aldrich, Milan, Italy). After washing, membranes were incubated for $1 \mathrm{~h}$ at room temperature with a 1/3000 dilution in TTBS/milk of an HRP-conjugated goat antimouse IgG (Dako). The visualization of $\beta$ actin was used to ensure equal sample loading in each lane. Proteins were detected by enhanced chemiluminescence detection system (Amersham Pharmacia Biotech) and quantification was achieved by densitometric scanning using NIH ImageJ software.

\section{Statistical analysis}

All results are reported as the mean values \pm standard error (SE) of at least three experiments. Statistical analysis was performed with Student's $t$-test for unpaired data and differences were considered significant for $\mathrm{P}<0.05$. Analysis was performed with SPSS 21.0.

\section{Results}

\section{Clinical data}

In all the 11 cases, the lesion was located in the dorsal scapular region. All patients under- went surgical complete resection; none suffered a recurrence. Macroscopically, our specimens appeared as irregular masses with indistinct borders and hard elastic consistence. Cut surface displays strands of white and yellow tissue representing adipose tissue, intermingled with fibroelastic tissue.

\section{Microscopic findings}

Histological analysis carried out via standard staining (hematoxylin-eosin) revealed the presence of islets of fatty tissue and a moderate cellular component (fibroblasts) associated with intensely eosinophilic matrix with coarse collagen bands and straggling elastic fibers. The elastic nature of fibers embedded in this fibrocollagenous matrix was also confirmed immunohistochemically, and compared to elastic fibers pattern of ligamentum flavum (Figure 1 A-D). Alcian blue pH 2.5 staining with and without testicular bovine

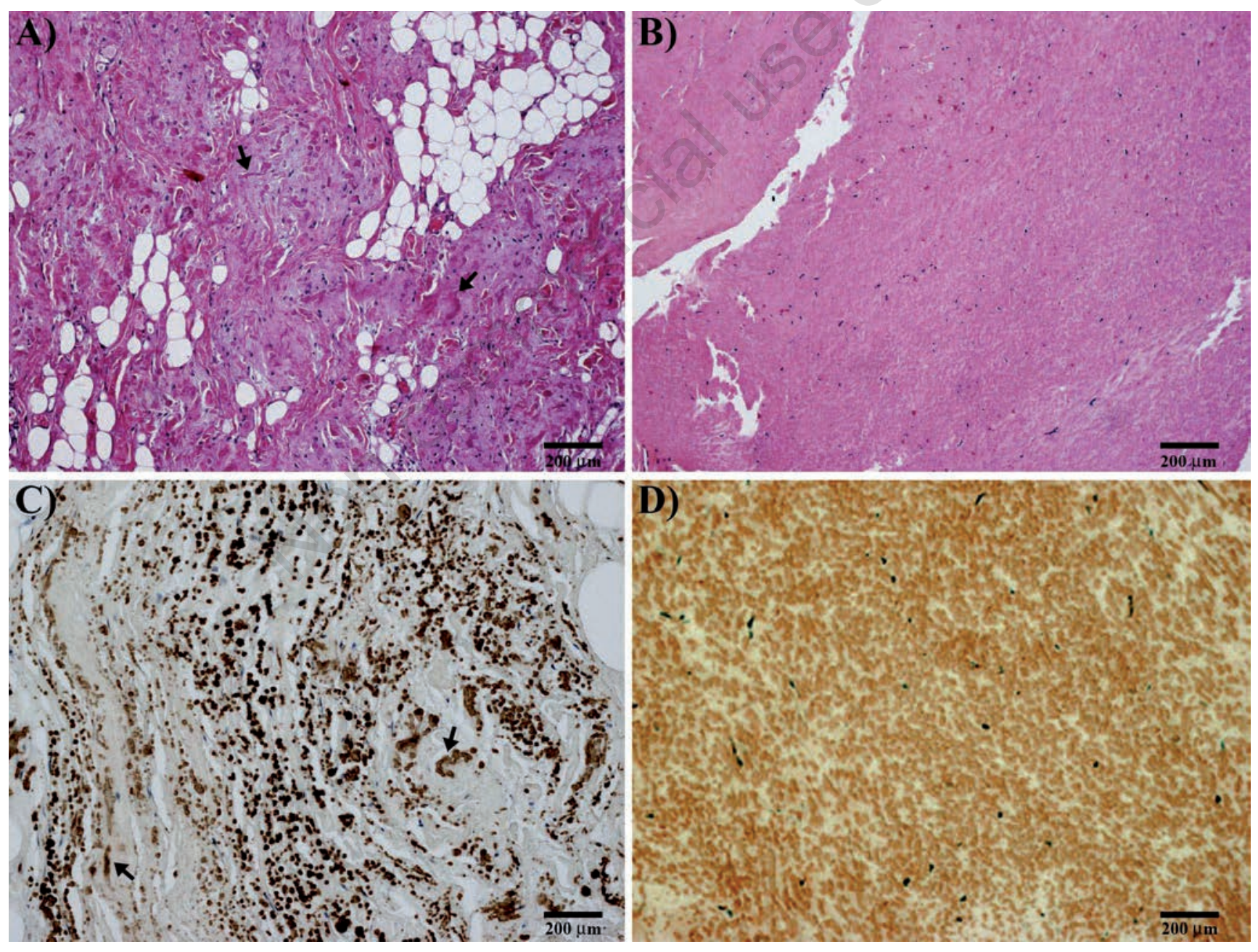

Figure 1. A) Microscopic findings of elastofibroma; elastic connective is intermixed with fibrous tissue (H\&E; arrows indicating elastic fibers). B) Ligamentum flavum: note the regular and monotonous structure (H\&E). C) Elastofibroma; immunohistochemical stain for elastic fibers: note the irregular arrangement of coarse elastic fibers (arrows). D) Ligamentum flavum; immunohistochemical stain for elastic fibers: note the uniform arrangement of elastic fibers. 
hyaluronidase treatment indicated the presence of considerable amount of hyaluronic acid (Figure $2 \mathrm{~A}, \mathrm{~B})$.

\section{Immunohistochemical findings}

The presence of mast cells tryptase-positive was reported in both central as well as vascularized peripheral regions of ED (Figure 3 A,B). In addition, diffuse positivity for CD34 was found in the spindle-shaped cells between the collagen fibers and, more relevant in perivascular region (Figure 3 C,D). Stroma and interspersed spindle cells of ED were positive for both periostin and tenascin-C, with a prominent expression around peripheral vessels more than central area (Figure $4 \mathrm{~A}, \mathrm{~B}$ ). In addition, periostin resulted less expressed than tenascin-C in stromal component of the
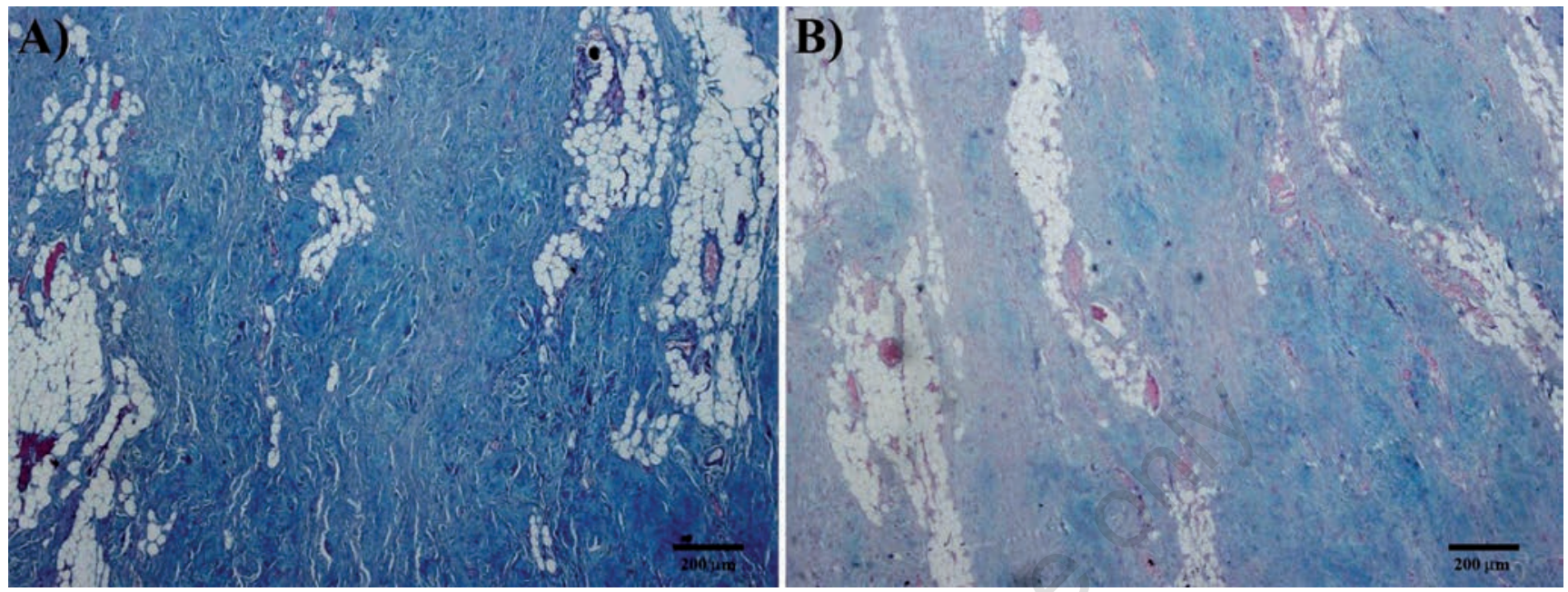

Figure 2. Results of special stains of elastofibroma. A) Alcian Blue pH 2.5. B) Alcian Blue pH 2.5 after treatment with testicular hyaluronidase. Considerable amount of hyaluronic acid is observed in the lesion.

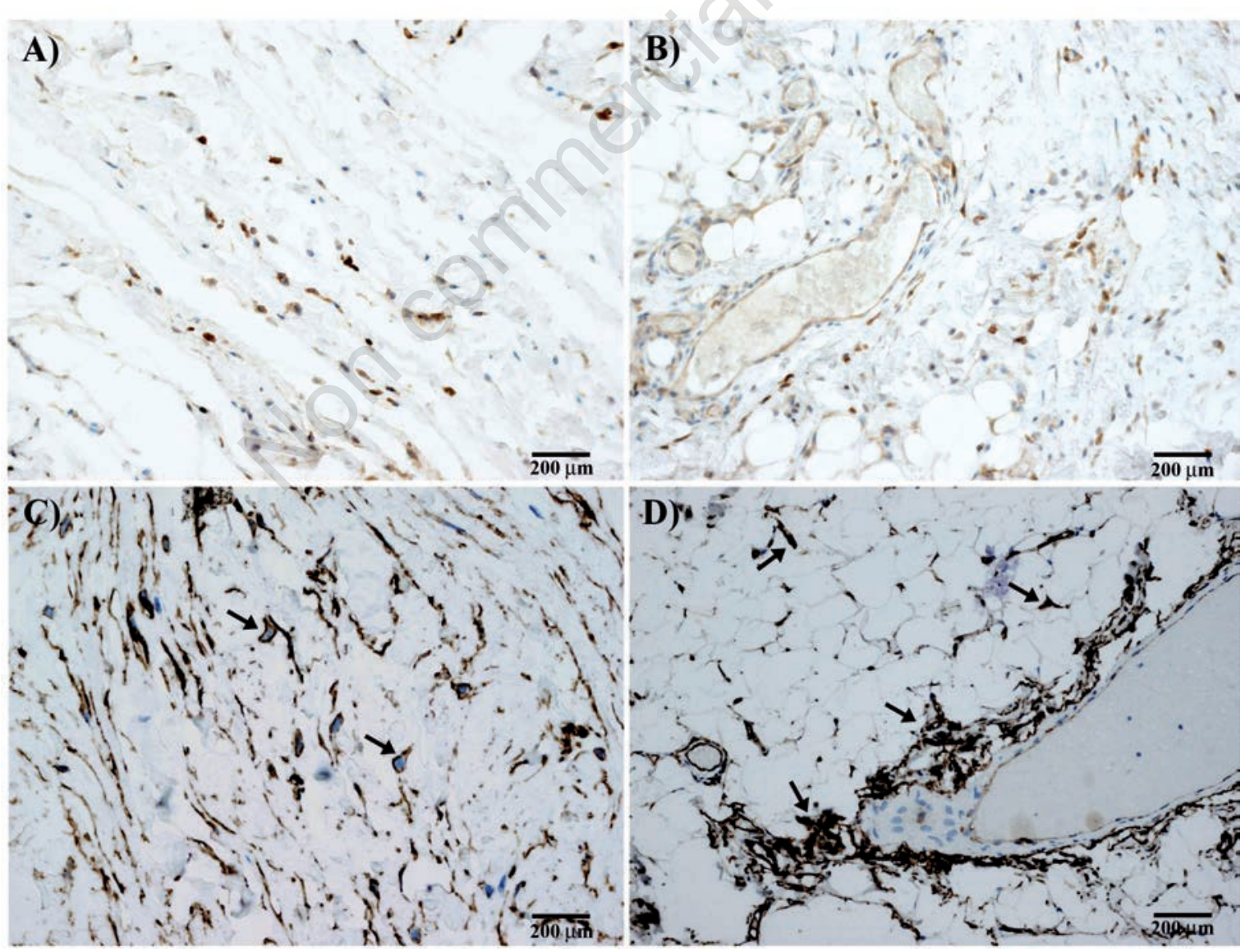

Figure 3. Immunohistochemical results of elastofibroma. Dark brown stained mast cells were positive for tryptase in central fibrous (A) and peripheral vascularized (B) area of elastofibroma. Many fibroblasts are also positive for CD34 in central (C; arrows) and peripheral (D) area of elastofibroma. Note in (D) the perivascular but also scattered distribution of cells in the fibroadipose tissue (arrows). 
central area of ED (Figure 4 B,D). The positive signals for the antibodies used in this study were observed in all cases of ED studied. Interestingly, a strong positivity for periostin was reported in ligamentum flavum, so that it was used as positive control (Figure 4C). Immunohistochemical results obtained from the 11 cases are also presented in a tabular form (Table 2).

\section{Immunofluorescence findings}

Double immunofluorescence staining for CD34 and periostin or tenascin-C is similar to that observed in immunohistochemistry. CD34

Table 2. Immunohistochemical findings of patients with elastofibroma dorsi.

\begin{tabular}{|c|c|c|c|c|c|c|c|c|c|c|c|}
\hline & Case 1 & Case 2 & Case 3 & Case 4 & Case 5 & Case 6 & Case 7 & Case 8 & Case 9 & Case 10 & Case 11 \\
\hline \multicolumn{12}{|l|}{ Periostin } \\
\hline Central & + & + & + & + & + & + & + & + & + & + & ++ \\
\hline Peripheral & +++ & +++ & +++ & ++ & +++ & +++ & +++ & +++ & +++ & +++ & +++ \\
\hline \multicolumn{12}{|l|}{ Tenascin-C } \\
\hline Central & + & + & ++ & ++ & ++ & ++ & ++ & ++ & ++ & ++ & ++ \\
\hline Peripheral & +++ & +++ & +++ & +++ & +++ & +++ & +++ & +++ & +++ & ++ & +++ \\
\hline \multicolumn{12}{|l|}{ Elastin } \\
\hline Central & ++ & ++ & ++ & ++ & ++ & ++ & ++ & ++ & ++ & ++ & ++ \\
\hline Peripheral & + & + & + & + & + & + & + & + & + & + & + \\
\hline
\end{tabular}

+ , low stain intensity; ++ , intermediate stain intensity; +++ , high stain intensity.
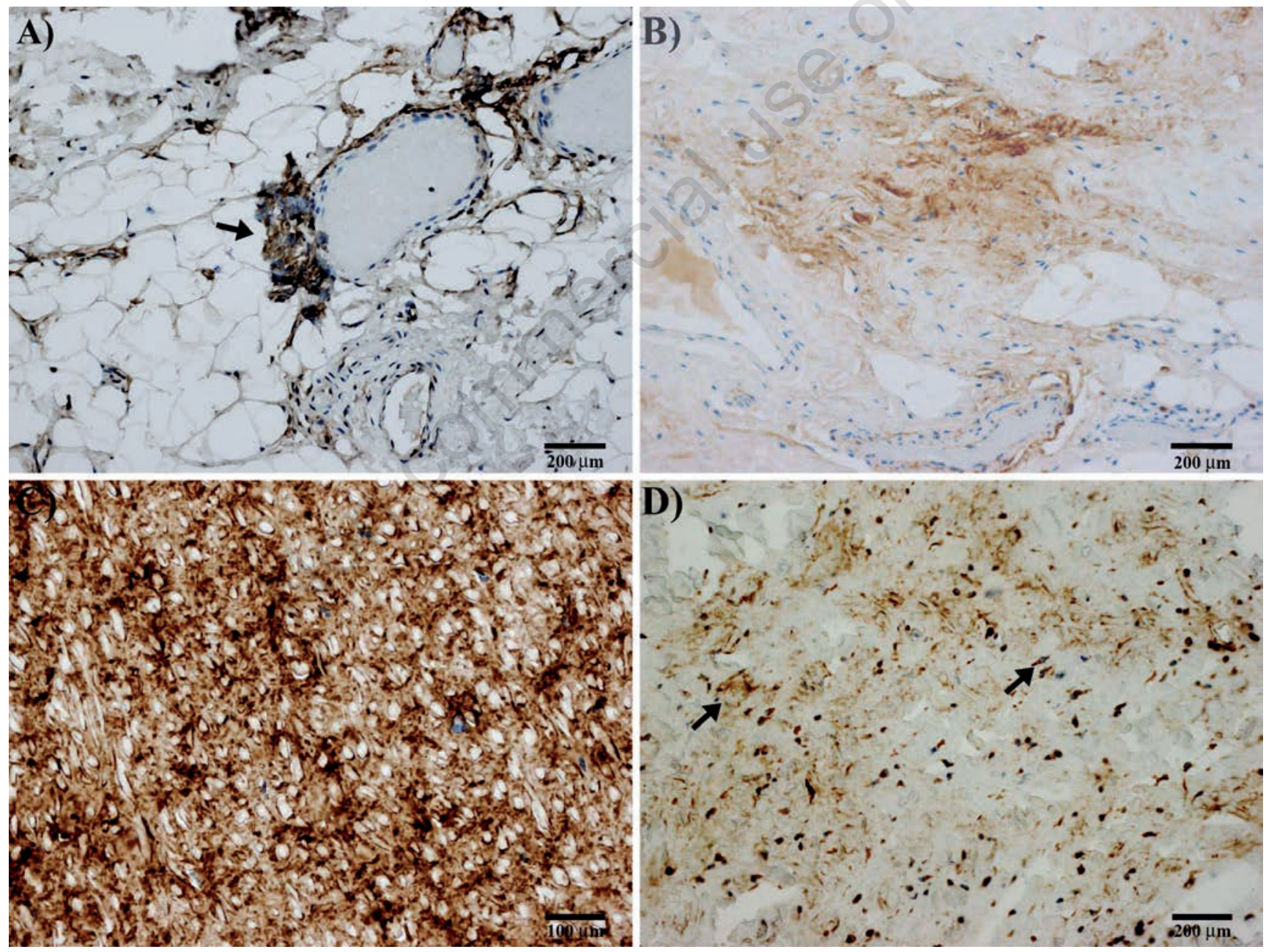

Figure 4. Immunohistochemical results of elastofibroma. A) Immunostaining for periostin in peripheral vascularized part of elastofibroma; note the staining of an angiogenetic perivascular tuft of cells, sign of an endothelial-mesenchymal transition (arrow). B) Immunostaining for periostin in the central area of elastofibroma; note the lower positivity for periostin in the stroma. C) Strong staining for periostin is observed in ligamentum flavum. D) Immunostaining for tenascin-C in elastofibroma; tenascin-C positivity in the stroma and cells scattered in central part of elastofibroma (arrows); perivascular positivity for tenascin-C is also observed in the peripheral part of the lesion (not shown). 
positivity was reported in interspersed spindleshaped cells as well as in perivascular region (Figure 5 A-D). Positive immunohistochemical signals of periostin were observed diffusely and intensely around peripheral vessels, while they were weak in the central area; both stroma and spindle cells resulted to be positive (Figure 5 A,B). Similarly, positivity for tenascin-C was reported in stroma, interspersed spindle cells and perivascular region of ED; also in this case, expression in peripheral area was more prominent than the central area (Figure 5 C,D).

\section{Correlation between confluence stage and elastin expression in HUVEC}

Elastin protein levels were found to be heav- ily influenced by the cell growing density (Figure 6A). Statistical analysis showed that elastin expression was significantly higher ( $>9.5$ times) in HUVEC at $20 \%$ of confluence when compared to the averaged levels of the other confluence stages (Figure 6B).

\section{Discussion}

In our analysis, we confirmed the presence of CD34-positive spindle cells, fibroblast-like, scattered in a dense mixture of fibers associated with an amorphous matrix of proteoglycan. Mast cells tryptase-positive were diffused throughout the lesion and, above all, around peripheral vessels. Based on these data, and on the fact that many studies recognized mast cells as a key stimulus for fibroblasts, ${ }^{23,24}$ we suggest the involvement of both mast cells tryptase-positive and fibroblasts CD34-positive in elastofibroma development. Interestingly, mast cells and fibroblasts could contribute to elastofibroma pathogenesis either independently or by cross-talking mechanisms. In the first hypothesis, mast cells produce proteoglycans, hyaluronic acid, chondroitin sulphate, and TGF- $\beta$, which might contribute to matrix remodeling and angiogenesis (Figure 7)..$^{24-26}$

As a matter of fact, alcian blue staining with and without testicular bovine hyaluronidase treatment confirm the presence of a large amount of hyaluronic acid. At the same time,
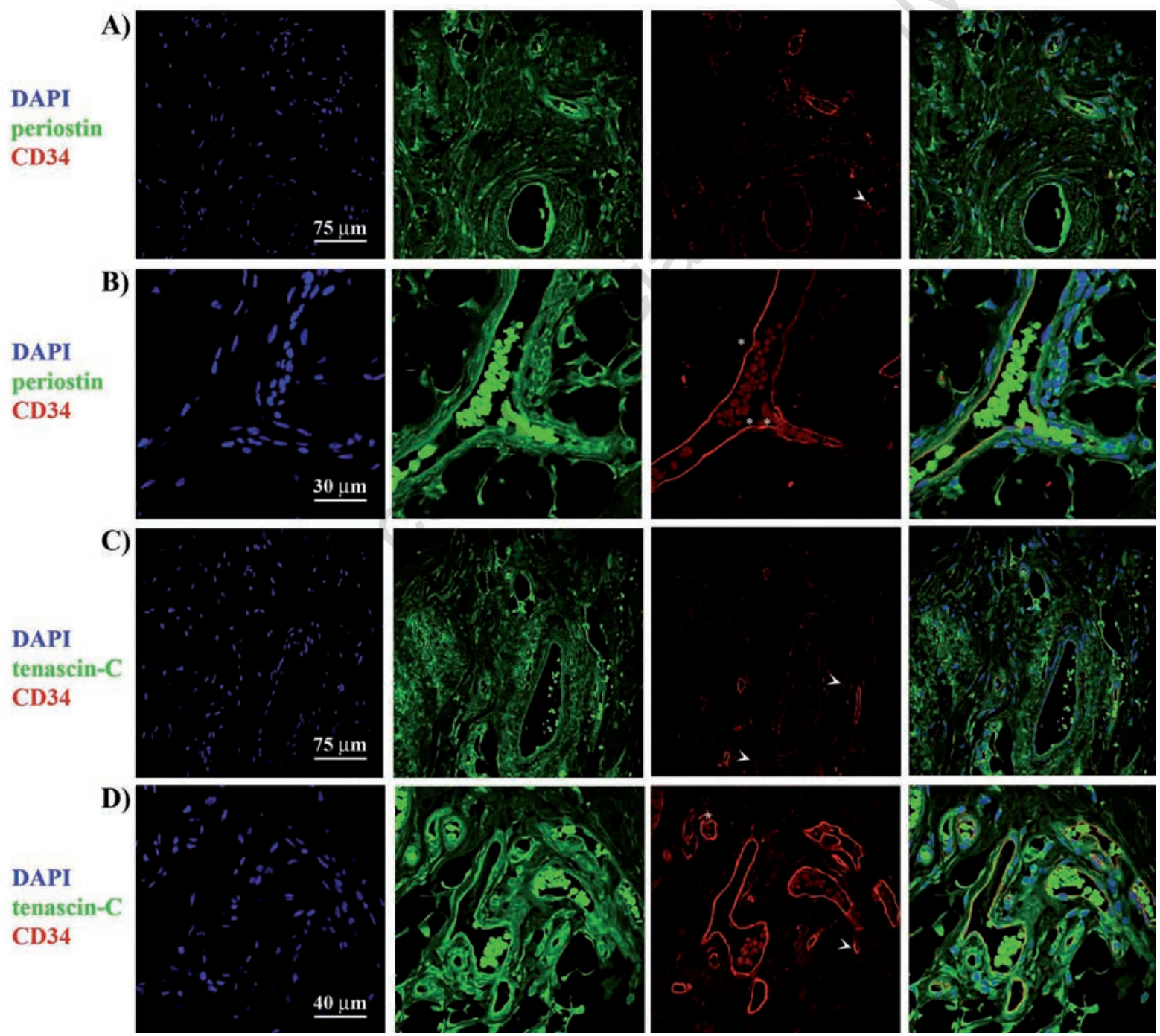

Figure 5. Colocalization of CD34 and mesenchymal markers periostin or tenascin-C. Double immunofluorescence staining with the antibodies against periostin (green) and CD34 (red) in central (A) and peripheral (B) area of the elastofibroma dorsi. Double immunofluorescence staining with the antibodies against tenascin-C (green) and CD34 (red) in central (C) and peripheral (D) area of the elastofibroma dorsi; arrows indicate the positivity for CD34 in interspersed cells, while asterisks indicate the perivascular positivity for CD34. 
A

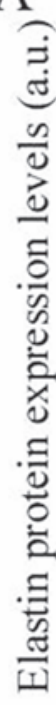



B

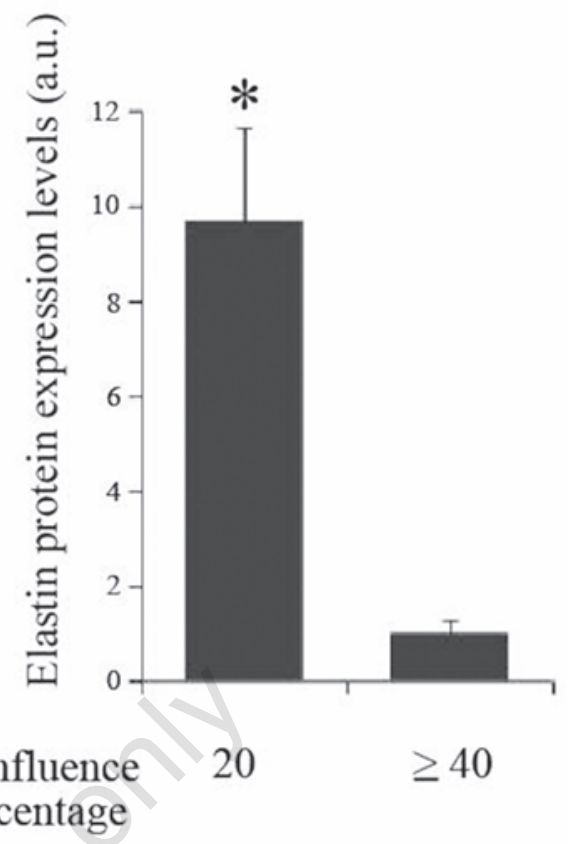

\section{$\beta$-actin}

Confluence .
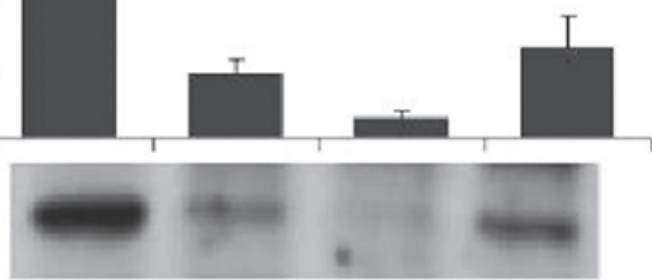
percentage

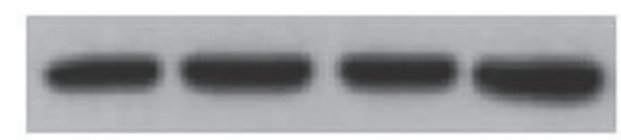

$\begin{array}{llll}20 & 40 & 60 & 100\end{array}$

\section{Confluence $\quad 20 \quad \geq 40$ percentage}

Figure 6. A,B) Levels of elastin in HUVEC cell cultures at different confluence densities; a.u., arbitrary unit; ${ }^{*} \mathrm{P}<0.05$.

fibroblast activation
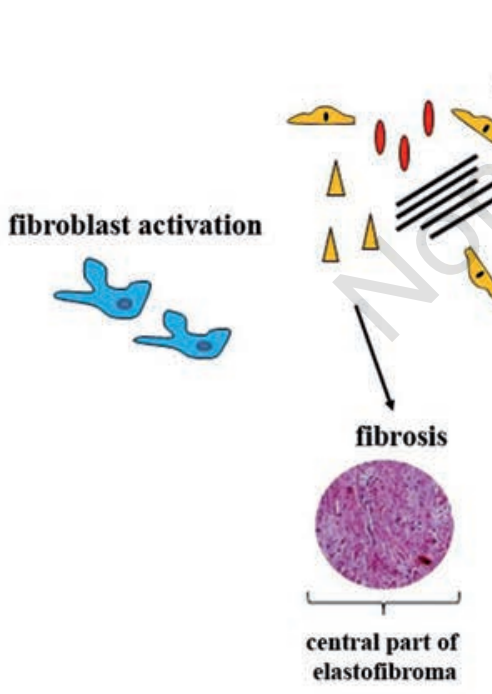

$\Delta$

ECM remodelling dothelial-mesenchymal transition
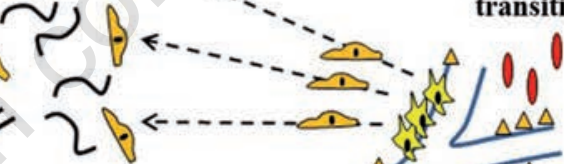

angiogenesis
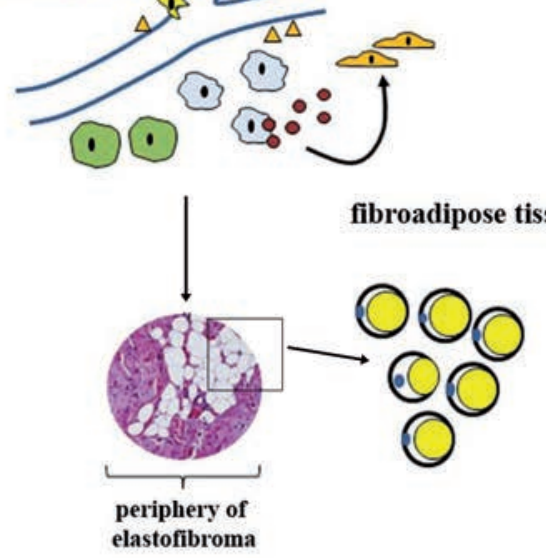

g

(1)

macrophage

(1) mast cell

- TGF- $\beta$

$\sim$ elastin

tenascin-C

$\triangle$ periostin

collagen

adipocyte

fibroblast CD34+

Figure 7. Elastofibroma pathogenesis. Chronic mechanical strain or genetic predisposition account for excessive fibroblast activation and accumulation of ECM components. Specific positional cues also induce endothelial-mesenchymal transition events. Extravasating macrophages and mast cells develop in the tissue and contribute to fibroblasts activation. In a later stages, the persistent presence of these cells and profibrotic stimuli such as TGF- $\beta$, account for progressive development of fibrosis and fat accumulation. A considerable amount of abnormal elastic fibers is observed in the central part of the lesion, where CD34-positive fibroblasts grown at low density. 
fibroblast-derived periostin and tenascin-C were detected throughout the lesion, and, above all, around vessels. This finding fits well with other studies indicating that matricellular proteins could be incorporated in ECM of remodeling tissues not only during development but also in fibrotic ECM and tumor associated stroma. ${ }^{27}$

What are the stimuli for tenascin- $\mathrm{C}$ and periostin production? According to recent literature, the production of the tenascin- $\mathrm{C}$ and periostin (component of ground substance), as well as of elastin and collagen (structural proteins), by activated fibroblasts, can occur as a consequence of mechanical strain. ${ }^{28-30}$ Consistent with this hypothesis, periostin has been widely recognized as matricellular protein expressed in collagen-rich tissues subject to constant mechanical stresses, such as periosteum, periodontal ligament, and human intervertebral discs. ${ }^{31-34}$ How the release of tenascin- $\mathrm{C}$ and periostin in ECM contributes to the pathogenesis of elastofibroma? From a functional point of view, tenascin-C is involved in embryonic development, wound healing, cancer invasion, and regeneration; ${ }^{35}$ similarly, it appears that periostin, firstly recognized as protein specifically expressed in periosteal tissues ${ }^{36}$ is expressed in a wide variety of normal adult and fetal tissues, under stress conditions and in cancer. ${ }^{33,37,38}$ Notably, in a previous study it was suggested that periosteal-derived cells may account for ED development; ${ }^{15}$ however, we do not have any evidences which could confirm or exclude this hypothesis. Tenascin-C and periostin cross-talk mechanisms, as well as interaction with other ECM molecules, contribute to collagen fibrillogenesis that occurs in cardiac fibrosis. ${ }^{39-42}$ Therefore, the expression pattern of periostin and tenascin- $\mathrm{C}$ reported in our study seem to suggest that tenascin-C-periostin interactions can also occur in pathogenesis of elastofibroma. To date, however, such interactions has still to be proved in ED. Interestingly, the pattern of periostin and tenascin-C reported in our study resemble very closely the distribution of CD34positivity, suggesting that endothelial-mesenchymal transition events can account for neovascularization in elastofibroma. According to our previous studies, showing a correlation between the number of tryptase-positive mast cells and angiogenesis in cardiac myxoma, pancreatic ductal adenocarcinoma, and neoplastic alterations of gastrointestinal tract, ${ }^{43-47}$ we hypothesize that mast cells could play a role in angiogenesis occurring in ED. Indeed, the involvement of mast cells in angiogenesis has been largely documented. ${ }^{48,49}$ Consistent with our study, it was reported that ED as well as gastrointestinal elastofibroma can develop from perivascular fibrotic lesions containing elastic fibers at various degree of maturation..$^{50}$ As far as altered morphology of the elastic fibers in elastofibroma is concerned, its origin is controversial. Some authors suggest that it might be due to genetic predisposition and, ${ }^{51}$ in particular, to genomic abnormalities involving genes of elastic fibers metabolism. It's known that after deposition, tropoelastin production is reduced and there is very little turnover of the mature, cross-linked form of the eventual elastin. On the contrary, degradation of elastic fibers occurs spontaneously as a consequence of aging and in chronic inflammatory conditions. . $^{52-54}$ Moreover, despite the little evidence of elastogenesis in adult tissues, ${ }^{55}$ in the event of injury, the production of tropoelastin can be quickly restarted, even though it occurs as an improper process. ${ }^{56,57}$ Interestingly, in the present study elastic connective tissue results to be more prominent in the central part of the lesion than the vascularized periphery. This observation fits well with our study showing as elastin level is heavily influenced by the cell growing density in HUVEC cultures. It's known that HUVEC cells are a heterogeneous population of cells with different proliferative and angiogenesis capability, ${ }^{58}$ and in vitro can synthesize, secret and deposit enough extracellular proteins for their adherence. ${ }^{59,60}$ In our study, HUVEC cultures at $20 \%$ of confluence display higher expression levels of elastin (>9.5 fold) with respect to the averaged levels reported in cultures at higher confluence. These data seem to suggest a transition from a synthetic to a more differentiated phenotype when cell density increased, providing us a useful model for elastin pattern reported in ED. In this scenario, the lower content in elastin reported in periphery respect to central part of the lesion could reflect the higher level of vascularization. Therefore, we think that the large amount of elastic fibers in ED could derive from a reactivation of tropoelastin production in fibroblasts, during mechanical or hypoxic injury, and elastic fibers pattern reflects fibroblasts density.

In conclusion, our work provides a detailed description of molecular organization of ECM in elastofibroma. The results suggest that matricellular proteins periostin and tenascin$\mathrm{C}$, together with collagen and elastin, take part in elastofibroma development, most probably via a direct involvement in fibrotic events (Figure 7). In addition, we suggest that both periostin and tenascin-C may play a pivotal role in neoangiogenesis occurring in $\mathrm{ED}$, so that their presence might allow the development of alternative therapeutic strategies in the future. ${ }^{61}$

\section{References}

1. El Hammoumi M, Qtaibi A, Arsalane A, El Oueriachi F, Kabiri el H. Elastofibroma dorsi: clinicopathological analysis of 76 cases. Korean J Thorac Cardiovasc Surg 2014;47:111-6.

2. Hisaoka M, Nishio JN. Elastofibroma, p. 53-4. In: DM Fletcher, JA Bridge, CW Hogendoorn, F Mertens (eds.), WHO classification of tumors of soft tissue and bone. International Agency for research on cancer, Lyon: 2013.

3. Karakurt 0, Kaplan T, Gunal N, Gulbahar G, Kocer B, Han S, et al. Elastofibroma dorsi management and outcomes: review of 16 cases. Interact Cardiovasc Thorac Surg 2014;18:197-201.

4. Naylor MF, Nascimento AG, Sherrick AD, McLeod RA. Elastofibroma dorsi: radiologic findings in 12 patients. AJR Am J Roentgenol 1996;167:683-7.

5. Schick S, Zembsch A, Gahleitner A, Wanderbaldinger P, Amann G, Breitenseher M, et al. Atypical appearance of elastofibroma dorsi on MRI: case reports and review of the literature. $\mathrm{J}$ Comput Assist Tomogr 2000;24:288-92.

6. Tamimi MI, Sesma SP, Perez LA, Martinez MJ, Vazquez ML, Tamimi F. Sensitivity and positive predictive value of magnetic resonance imaging in the diagnosis of elastofibroma dorsi: review of fourteen cases. $\mathrm{J}$ Shoulder Elbow Surg 2013;22:57-63.

7. Kara M, Dikmen E, KaraSA, Atasoy P. Bilateral elastofibroma dorsi: proper positioning for an accurate diagnosis. Eur $\mathrm{J}$ Cardiothorac Surg 2002;22:839-41.

8. Pilge H, Hesper T, Holzapfel BM, Prodinger PM, Straub M, Krauspe R. Elastofibroma: clinical results after resection of a rare tumor entity. Orthop Rev (Pavia) 2014;6:5329.

9. Ramos R, Ureña A, Macía I, Rivas F, Ríus X, Armengol J. Elastofibroma dorsi: an uncommon and under-diagnosed tumour. Arch Bronconeumol 2011;47:262-3. 1

10. Kuroda N, Hamaguchi N, Ohara M, Hirouchi T, Mizuno K, Hayashi Y, et al. Elastofibroma: a histochemical, immunohistochemical, and ultrastructural study of two patients. Med Mol Morphol 2008;41: 179-82.

11. Giebel GD, Bierhoff E, Vogel J. Elastofibroma and pre-elastofibroma - A biopsy and autopsy study. Eur J Surg Oncol 1996;22:93-6.

12. Järvi $\mathrm{OH}$, Saxén AE, Hopsu-Havu VK, Wartiovaara JJ, Vaissalo VT. Elastofibroma-a degenerative pseudotumor. Cancer 1969;3:42-63.

13. Stemmermann GN, Stout AP. Elasto- 
fibroma dorsi. Am J Clin Pathol 1962;37:499-506.

14. Fukuda Y, Miyake H, Masuda Y, Masugi Y. Histogenesis of unique elastinophilic fibers of elastofibroma: ultrastructural and immunohistochemical studies. Hum Pathol 1987;18:424-9.

15. Kumaratilake JS, Krishnan R, LomaxSmith J, Cleary EG. Elastofibroma: disturbed elastic fibrillogenesis by periostealderived cells? An immunoelectron microscopic and in situ hybridization study. Hum Pathol 1991;22):1017-29.

16. McComb EN, Feely MG, Neff JR, Johansson SL, Nelson M, Bridge JA. Cytogenetic instability, predominantly involving chromosome 1, is characteristic of elastofibroma. Cancer Genet Cytogenet 2001;126:68-72.

17. Nishio JN, Iwasaki H, Ohjimi Y, Ishiguro M, Koga T, Isayama T, et al. Gain of Xq detected by comparative genomic hybridization in elastofibroma. Int $\mathrm{J}$ Mol Med 2002;10:277-80.

18. Hernández JL, Rodríguez-Parets J0, Valero JM, Muñoz MA, Benito MR, Hernandez JM, et al. High-resolution genome-wide analysis of chromosomal alterations in elastofibroma. Virchows Arch 2010; 456:681-7.

19. Hisaoka M, Hashimoto H. Elastofibroma: clonal fibrous proliferation with predominant CD34-positive cells. Virchows Arch 2006;448:195-9.

20. Ramos CV, Gillespie W, Narconis RJ. Elastofibroma. A pseudotumor of myofibroblasts. Arch Pathol Lab Med 1978;102:538-40.

21. Wolfe BL, Rich CB, Goud HD, Terpstra AJ, Bashir M, Rosenbloom J, et al. Insulin-like growth factor-I regulates transcription of the elastin gene. J Biol Chem 1993;268: 12418-26.

22. Sen S, Bunda S, Shi J, Wang A, Mitts TF, Hinek A. Retinoblastoma protein modulates the inverse relationship between cellular proliferation and elastogenesis. $\mathrm{J}$ Biol Chem 2011;286:36580-91.

23. Gailit J, Marchese MJ, Kew RR, Gruber BL. The differentiation and function of myofibroblasts is regulated by mast cell mediators. J Invest Dermatol 2001;117:1113-9.

24. Hügle T. Beyond allergy: the role of mast cells in fibrosis. Swiss Med Wkly 2014;144:w13999.

25. Eggli PS, Graber W. Cytochemical localization of hyaluronan in rat and human skin mast cell granules. J Invest Dermatol 1993;100:121-5.

26. Park D, Kim Y, Kim H, Kim K, Lee YS, Choe $\mathrm{J}$, et al. Hyaluronic acid promotes angiogenesis by inducing RHAMM-TGF receptor interaction via CD44-PKC. Mol Cells
2012;3:563-74.

27. Murphy-Ullrich JE, Sage EH. Revisiting the matricellular concept. Matrix Biol 2014;37:1-14.

28. Udalova IA, Ruhmann M, Thomson SJ, Midwood KS. Expression and immune function of tenascin-C. Crit Rev Immunol 2011;31:115-145.

29. Yamashita 0, Yoshimura K, Nagasawa A, Ueda K, Morikage N, Ikeda Y, et al. Periostin links mechanical strain to inflammation in abdominal aortic aneurysm. PLoSOne 2013;8:e79753.

30. Bing Z, Linlin L, Jianguo Y, Shenshen R, Ruifang R, Xi Z. Effect of mechanical stretch on the expressions of elastin, LOX and Fibulin-5 in rat BMSCs with ligament fibroblasts co-culture. Mol Biol Rep 2012;39:6077-85.

31. Wang D, Oparil S, Feng JA, Li P, Perry G, Chen LB, et al. Effects of pressure overload on extracellular matrix expression in the heart of the atrial natriuretic peptide-null mouse. Hypertension 2003;42:88-95.

32. Lindner V, Wang Q, Conley BA, Friesel RE, Vary CP. Vascular injury induces expression of periostin: implications for vascular cell differentiation and migration. Arterioscler Thromb Vasc Biol 2005;25:77-83.

33. Goetsch SC, Hawke TJ, Gallardo TD, Richardson JA, Garry DJ. Transcriptional profiling and regulation of the extracellular matrix during muscle regeneration. Physiol Genomics 2003;14:261-71.

34. Gruber HE, Norris RA, Kern MJ, Hoelscher GL, Ingram JA, Zinchenko $\mathrm{N}$, et al. Periostin is expressed by cells of the human and sand rat intervertebral discs. Biotech Histochem 2011;86:199-206.

35. Midwood KS, Hussenet T, Langlois B, Orend G. Advances in tenascin-C biology. Cell Mol Life Sci 2011;68:3175-99.

36. Horiuchi K, Amizuka N, Takeshita S, Takamatsu H, Katsuura M, Ozawa H, et al. Identification and characterization of a novel protein, periostin, with restricted expression to periosteum and periodontal ligament and increased expression by transforming growth factor beta. J Bone Miner Res 1999;14:1239-49.

37. Soltermann A, Tischler V, Arbogast S, Braun J, Probst-Hensch N, Weder W, et al. Prognostic significance of epithelial-mesenchymal and mesenchymal-epithelial transition protein expression in non-small cell lung cancer. Clin Cancer Res 2008;14:7430-7.

38. Takeshita S, Kikuno R, Tezuka K, Amann E. Osteoblast-specific factor 2: cloning of a putative bone adhesion protein with homology with the insect protein fasciclin I. Biochem J 1993;294(Pt 1):271-8.

39. Kii I, Nishiyama T, Li M, Matsumoto K,
Saito M, Amizuka N, et al. Incorporation of tenascin-C into the extracellular matrix by periostin underlies an extracellular meshwork architecture. J Biol Chem 2010;285: 2028-39.

40. Midwood K, Sacre S, Piccinini AM, Inglis J, Trebaul A, Chan E, et al. Tenascin-C is an endogenous activator of Toll-like receptor 4 that is essential for maintaining inflammation in arthritic joint disease. Nat Med 2009;15:774-80.

41. Imanaka-Yoshida K. Tenascin-C in cardiovascular tissue remodeling: from development to inflammation and repair. Circ $\mathrm{J}$ 2012;76:2513-20.

42. Oka T, Xu J, Kaiser RA, Melendez J, Hambleton M, Sargent MA, et al. Genetic manipulation of periostin expression reveals a role in cardiac hypertrophy and ventricular remodeling. Circ Res 2007;101: 313-21.

43. Donato G, Conforti F, Camastra C, Ammendola M, Donato A, Renzulli A. The role of mast cell tryptases in cardiac myxoma: Histogenesis and development of a challenging tumor. Oncol Lett 2014;8:37983.

44. Ammendola M, Sacco R, Donato G, Zuccalà V, Russo E, Luposella M, et al. Mast cell positivity to tryptase correlates with metastatic lymph nodes in gastrointestinal cancer patients treated surgically. Oncology 2013;85:111-6.

45. Ammendola M, Sacco R, Sammarco G, Donato G, Zuccalà V, Romano R, et al. Mast Cells Positive to Tryptase and c-Kit Receptor Expressing Cells Correlates with Angiogenesis in Gastric Cancer Patients Surgically Treated. Gastroenterol Res Pract 2013;2013:703163.

46. Ammendola M, Sacco R, Sammarco G, Donato G, Montemurro S, Ruggieri E, et al. Correlation between serum tryptase, mast cells positive to tryptase and microvascular density in colo-rectal cancer patients: possible biological-clinical significance. PLoSOne 2014;9:e99512.

47. Ammendola M, Sacco R, Sammarco G, Donato G, Zuccalà V, Luposella $\mathrm{M}$, et al. Mast cells density positive to tryptase correlates with angiogenesis in pancreatic ductal adenocarcinoma patients having undergone surgery. Gastroenterol Res Pract 2014;2014:951957.

48. Soucek L, Lawlor ER, Soto D, Shchors K, Swigart LB, Evan GI. Mast cells are required for angiogenesis and macroscopic expansion of Myc-induced pancreatic islet tumors. Nat Med 2007;13):1211-8.

49. Ribatti D, Ranieri G. Tryptase, a novel angiogenic factor stored in mast cell granules. Exp Cell Res 2014;pii:S00144827(14)00510-2. 
50. Kai K, Kusano K, Sakai M, Tabuchi M, Yunotani S, Miyazaki K, et al. Active neovascularization and possible vascular-centric development of gastric and periscapular elastofibromas. Virchows Arch 2009;454:181-8.

51. Scarpulla M, Accardi M, Abruzzo F, Vitale A, Abbruzzo A, Vitale G. Etiological hypothesis on five cases of elastofibroma dorsi. G Chir 2009;30:161-3.

52. Pierce RA, Mariani TJ, Senior RM. Elastin in lung development and disease. Ciba Found Symp 1995;192:199-212.

53. Thompson RW, Parks WC. Role of matrix metalloproteinases in abdominal aortic aneurysms. Ann NY Acad Sci
1996;800:157-74.

54. Cardoso WV, Sekhon HS, Hyde DM, Thurlbeck WM. Collagen and elastin in human pulmonary emphysema. Am Rev Respir Dis 1993;147:975-81.

55. Slack HG. Metabolism of elastin in the adult rat. Nature 1954;174:512-3.

56. Wise SG, Weiss AS. Tropoelastin. Int J Biochem Cell Biol 2009;41:494-7.

57. Xie J, Huang W, Jiang J, Zhang Y, Xu Y, Xu C, et al. Differential expressions of lysyl oxidase family in ACL and MCL fibroblasts after mechanical injury. Injury 2013;44: 893-900.

58. Zheng YW, Nie YZ, Tsuchida T, Zhang RR, Aoki K, Sekine K, et al. Evidence of a sophisticatedly heterogeneous population of human umbilical vein endothelial cells. Transplant Proc 2014;46:1251-3.

59. Clark RA, Folkvord JM, Nielsen LD. Either exogenous or endogenous fibronectin can promote adherence of human endothelial cells. J Cell Sci 1986;82:263-80.

60. Solomon DE. An in vitro examination of an extracellular matrix scaffold for use in wound healing. Int J Exp Pathol 2002;83:2 09-16.

61. Zhu M, Saxton RE, Ramos L, Chang DD, Karlan BY, Gasson JC, et al. Neutralizing monoclonal antibody to periostin inhibits ovarian tumor growth and metastasis. Mol Cancer Ther 2011;10:1500-8. 